\title{
Glucose controls sex-related growth rate differences of bovine embryos produced in vitro
}

\author{
K. Bredbacka and P. Bredbacka* \\ Department of Animal Breeding, Agricultural Research Centre FIN-31600 Jokioinen, Finland
}

\begin{abstract}
The objective of this study was to determine whether the presence of glucose in the culture medium causes more growth of male embryos than of female embryos in cows. Oocytes matured and fertilized in vitro were cultured from 24 to $48 \mathrm{~h}$ after insemination in CRIaa medium with or without $5.56 \mathrm{mmol}$ glucose $\mathrm{l}^{-1}$. At the end of culture the mean numbers of cells of the cleaved embryos were $5.07( \pm 0.16)$ in glucose-free medium and 5.29 $( \pm 0.17)$ in medium with glucose $(P=0.86)$. Without glucose in the medium, the least square mean was 0.22 cells higher in males than in females. This difference was not significant $(P=0.44)$. However, in the presence of glucose this difference was 1.25 cells in favour of males $(P=0.0001)$. The possibility that the sex difference is linked with growth stimulating effects of oxygen radicals is discussed.
\end{abstract}

\section{Introduction}

Several studies in mice (Tsunoda et al., 1985; Burgoyne, 1993; Valdivia et al., 1993; Zwingman et al., 1993; Peippo and Bredbacka, 1995) and cattle (Avery et al., 1991, 1992; Xu et al., 1992; Yadav et al., 1993) have suggested that male embryos develop faster than female embryos. Although Bondioli $e t$ al. (1989) reported a biased sex ratio in cow embryos produced in vivo, the growth difference appears to be enhanced by, if not limited to, the in vitro environment (Callesen et al, 1995; Peippo and Bredbacka, 1995). In cows there is evidence that this difference is initiated by the time of the first cleavage (Dominko and First, 1993; Yadav et al., 1993).

The reason for the tendency of males to develop faster is unknown. It has been suggested that the growth differences are caused by $Y$-chromosomal growth factors (Avery et al., 1989; Xu et al., 1992; Burgoyne, 1993; Ray et al., 1995) but the role of X-chromosomal enzymes has also been considered (Rieger, 1992; Burgoyne and Thornhill, 1995; Peippo and Bredbacka, 1995). During early development, both $X$ chromosomes in females are active, and one becomes inactivated during the blastocyst stage (Kratzer and Gartler, 1978; de la Fuente et al., 1993). Consequently, in mice at least, the expression of $X$-chromosomal genes encoding, for example, hypoxanthine phosphoribosyl transferase (HPRT) and glucose-6-phosphate dehydrogenase (G6PDH) is approximately twice as high in females than in males between the time of genome activation and $X$ chromosome inactivation (Epstein et al., 1978). These enzymes apparently play a role in decreasing intracellular concentrations of oxygen radicals (Rieger, 1992). Before $X$ chromosome inactivation, these concentrations therefore may be lower than in males.

The present study is based on the hypothesis that the growth rate difference between the sexes is caused by the

* Correspondence and reprint requests.

Received 18 July 1995. increased expression of G6PDH or HPRT in female embryos in the presence of glucose, resulting in a decreased production of oxygen radicals. This hypothesis was tested by culturing fertilized oocytes in vitro in media with or without glucose from 24 to $48 \mathrm{~h}$ after insemination. According to our hypothesis, the faster cleavage of male embryos is enhanced by glucose.

\section{Materials and Methods}

In vitro maturation

Cattle ovaries were obtained from an abattoir and transported to the laboratory at room temperature in $0.9 \%(\mathrm{w} / \mathrm{v}) \mathrm{NaCl}$ supplemented with 100 iu penicillin $\mathrm{ml}^{-1}$ and $100 \mu \mathrm{g}$ streptomycin $\mathrm{ml}^{-1}$. The oocytes were aspirated from follicles with a diameter of 3-8 mm. Only oocytes surrounded by cumulus cells were selected for maturation. Oocytecumulus complexes were washed twice in TALP-Hepes (Parrish et al., 1988). Hepes was obtained from Sigma (St Louis, MO). The maturation medium was TCMI99 (Sigma) supplemented with $0.25 \mathrm{mmol}$ sodium pyruvate $1^{-1}$, 2 mmol L-glutamine $\mathrm{I}^{-1}, 100$ iu penicillin $\mathrm{ml}^{-1}, 100 \mu \mathrm{g}$ streptomycin $\mathrm{ml}^{-1}, 2 \mu \mathrm{g} \mathrm{FSH} \mathrm{ml}{ }^{-1}$ (USDA-oFSH-18; USDA,

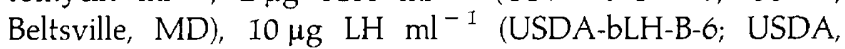
Beltsville, MD), $1 \mu \mathrm{g}$ oestradiol $\mathrm{ml}^{-1}$ (Sigma), $5 \%(\mathrm{v} / \mathrm{v}$ ) fetal calf serum and $5 \%(\mathrm{v} / \mathrm{v})$ oestrous cow serum. In each $500 \mu \mathrm{l}$ drop of medium, 40-50 oocyte-cumulus complexes were matured for $24 \mathrm{~h}$ under $5 \% \mathrm{CO}_{2}$ in air at $39^{\circ} \mathrm{C}$.

\section{In vitro fertilization}

After maturation, oocyte-cumulus complexes were washed in TALP-Hepes and transferred to $100 \mu$ l fertilization drops covered with embryo tested mineral oil (Sigma). The fertilization medium was fert-TALP (Parrish et al., 1988) Downloaded from Bioscientifica.com at 04/26/2023 01:59:46PM 
supplemented with $2 \mu \mathrm{g}$ heparin $\mathrm{ml}^{-1}, 20 \mu \mathrm{mol}$ penicillamine $1^{-1}, 10 \mu \mathrm{mol}$ hypotaurine $1^{-1}$ and $1 \mu \mathrm{mol}$ adrenaline $l^{-1}$ (Sigma). Frozen-thawed spermatozoa were washed twice in sperm-TALP (Parrish et al., 1988) and $1.5 \times 10^{6}$ spermatozoa $\mathrm{ml}^{-1}$ was added into each fertilization drop. After $24 \mathrm{~h}$ fertilization at $39^{\circ} \mathrm{C}$ in $5 \% \mathrm{CO}_{2}: 95 \%$ air, the cumulus cells were removed by vortexing.

\section{In vitro culture}

The oocytes were washed in glucose-free CRIaa-medium (Rosenkrans and First, 1991) and placed randomly into one of the two culture media: CRIaa (without glucose) and CRIaa supplemented with $5.56 \mathrm{mmol}$ glucose $\mathrm{l}^{-1}$. About $30-60$ embryos were cultured in each $500 \mu \mathrm{l}$ drop of medium covered with mineral oil at $39^{\circ} \mathrm{C}$ in a humidified atmosphere of $5 \% \mathrm{CO}_{2}$ in air. After culture for $24 \mathrm{~h}$ the number of cells of each embryo was recorded. Only cleaved embryos were used for further analysis.

\section{Sexing of embryos using PCR}

At the end of culture, the sex of individual cleaved embryos was determined using PCR (Saiki et al., 1988). Accessory spermatozoa were removed by removing the zonae pellucidae by brief exposure to Tyrode's solution ( $\mathrm{pH} \mathrm{1.8-2.0)}$ and washing three times in $0.5 \mathrm{ml}$ PBS with $6 \mathrm{mg}$ polyvinylpyrrolidone $\mathrm{ml}^{-1}$ (Sigma). With minor modifications, the embryos were sexed as described by Bredbacka and Peippo (1992), using primers designed to amplify the $Y$-chromosomal locus, $Z F Y$, and its $X$-chromosomal homologue, ZFX. Each embryo was placed in $1 \mu \mathrm{l}$ PBS + polyvinylpyrrolidone into a $0.5 \mathrm{ml}$ reaction tube filled with $9 \mu \mathrm{l}$ lysis buffer consisting of DynaZyme $^{(\mathrm{i} i \mathrm{i})}$ buffer (Finnzymes, Espoo, Finland), dNTPs, $\mathrm{MgCl}_{2}$ and $0.1 \mathrm{mg}$ proteinase $\mathrm{K} \mathrm{ml}^{-1}$ (Boehringer Mannheim, Mannheim, Germany). After lysis for $30 \mathrm{~min}$ at $37^{\circ} \mathrm{C}$, the mixture was overlaid with $25 \mu$ l DNAse-free mineral oil (Sigma) and then proteinase $\mathrm{K}$ was inactivated at $98^{\circ} \mathrm{C}$ for $10 \mathrm{~min}$. During the $3 \mathrm{~min}$ denaturation step of the first PCR cycle, $15 \mu \mathrm{l} \mathrm{MgCl}$-free DynaZyme (iii) buffer (including the primers and the polymerase) was added to each tube. The final $25 \mu \mathrm{l}$ reaction mixture consisted of $50 \mathrm{mmol} \mathrm{KCl} \mathrm{l} \mathrm{l}^{-\mathrm{I}}$, $1.5 \mathrm{mmol} \mathrm{MgCl} \mathrm{l}^{-1}, 10 \mathrm{mmol}$ Tris- $\mathrm{HCl} \mathrm{l}^{-1}(\mathrm{pH} \mathrm{8.8)}, 0.01 \%$ gelatin $(w / v), 0.1 \%$ Triton $X-100(v / v), 0.2 \mathrm{mmol} d N T P s l^{-1}$, $1.5 \mathrm{U}$ of DynaZyme ${ }^{(\mathrm{m})}$ polymerase (Finnzymes) and $10 \mathrm{pmol}$ of each primer. The amplification was carried out using an MJ Research Minicycler ${ }^{-\infty}$ and consisted of an initial denaturation for $3 \mathrm{~min}$ at $94^{\circ} \mathrm{C}$ followed by 50 cycles of $60 \mathrm{~s}$ at $94^{\circ} \mathrm{C}, 50 \mathrm{~s}$ at $54^{\circ} \mathrm{C}$ and $30-60 \mathrm{~s}$ at $72^{\circ} \mathrm{C}$. Finally, the samples were incubated for $5 \mathrm{~min}$ at $72^{\circ} \mathrm{C}$.

After PCR, a $10 \mu \mathrm{l}$ sample from each tube was added to a

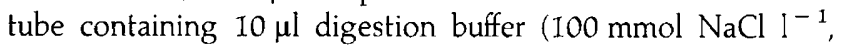
$18 \mathrm{mmol} \mathrm{MgCl}_{2} \mathrm{l}^{-1}, 5 \mathrm{U}$ endonuclease PstI, $10 \mathrm{mmol}$ Tris$\left.\mathrm{HCl} \mathrm{l}^{-1}, \mathrm{pH} 7.5\right)$. After digestion for $1-2 \mathrm{~h}$ the $\mathrm{Y}$-chromosomal homologue could be digested into fragments of $344 \mathrm{bp}$ and $103 \mathrm{bp}$, whereas the $X$-chromosomal homologue remained at $445 \mathrm{bp}$. Consequently, a male sample was characterized by the presence of all three fragments, whereas only the longest fragment could be observed in female samples. The fragment lengths were observed by UV illumination after electrophoresis on an ethidium bromide-stained $3 \%(\mathrm{w} / \mathrm{v})$ agarose gel $(\mathrm{Nu}$ Sieve ${ }^{13}$; FMC BioProducts, Rockland, ME) run at $8 \mathrm{~V} \mathrm{~cm}^{-1}$ for 30-45 min. Control samples were taken from embryo washing media and subjected to the same treatments as embryos.

\section{Estimation of parthenogenetic activation}

Since parthenogenetically activated oocytes are diagnosed as females, they represent a potential source of bias in assessing female embryo growth. Therefore some oocytes were treated as above but inseminated with dead spermatozoa to estimate the relative proportion of cleavage of parthenogenetically activated oocytes in the two culture media. Spermatozoa were killed by repeated freezing-thawing in fert-TALP.

\section{Statistical analysis}

The effect of sex on the number of cells of embryos was determined by analysis of variance, using the general linear model (SAS Institute Inc., Cary, NC, USA). The effect of replicate was included in the model, since it was significant. Comparison of cleavage rates between treatments and comparison of sex ratios to the 1:I ratio were carried out with the chi-squared test.

\section{Results}

Of the 11 replicates, three could not be used as a result of total PCR failure, probably owing to nuclease contamination of media used in zona pellucida removal. In the remaining eight replicates the cleavage rate was similar in glucose-free media and in media containing glucose $169.9 \%$ versus $63.8 \%$; $P=0.10$ ). Of the cleaved embryos, the sex of $91.3 \%$ could be determined. Of the embryos cultured without glucose, 100 were males and 108 were females. Embryos cultured in the presence of glucose included 91 males and 90 females. The sex ratio did not differ from the 1:1 ratio in either case.

The mean number of cells ( \pm SEM) was $5.07 \pm 0.16$ in culture without glucose and $5.29 \pm 0.17$ when glucose was present $(P=0.86)$. Without glucose in the medium, the least square mean was 0.22 cells higher in males compared with females. This difference was not significant $(P=0.44)$. However, in the presence of glucose, this difference was 1.25 cells in favour of males $(P=0.0001)$.

The incidence of parthenogenetic activation of oocytes inseminated with killed spermatozoa was 10 of 63 in the non-glucose and 8 of 63 in the glucose group $(P=0.61)$. At the end of culture, 15 of the 18 cleaved oocytes had developed to the two-cell stage. Of the remaining three parthenogenotes, two had three cells and one had four cells.

\section{Discussion}

The results presented here show that male embryos cleave faster than female embryos only in the presence of exogenous glucose. This is in agreement with our original assumption, and offers an explanation for previous observations of increased Downloaded from Bioscientifica.com at 04/26/2023 01:59:46PM via free access 
development of male embryos. To our knowledge, sex differences in growth have not been observed following culture in media without glucose. Many of the authors who observed faster growth in males cultured their embryos in Menezo's B2 (Avery et al., 1992; Marquant-LeGuienne et al., 1992; Xu et al., 1992), which contains a relatively high glucose concentration $\left(6.7 \mathrm{mmol} \mathrm{I^{-1 }}\right)$. Even when coculture with other cells is used with this medium, the amount of glucose would remain high especially at the beginning of culture. Furthermore, Gutierrez et al. (1993) observed an altered sex ratio of mouse embryos cultured in BMOC (medium containing glucose) but not in $\mathrm{CZB}$ (medium without glucose). Although glucose is only one of the differences between these media, the altered sex ratio could be attributed to glucose present in BMOC.

We tested the effect of glucose between 24 and $48 \mathrm{~h}$ after insemination. At $24 \mathrm{~h}$, the fertilized oocyte is at the S or G2 phase (Barnes and Eyestone, 1990). Our finding seems to rule out the possibility that earlier events (such as earlier fertilization or pronucleus formation) solely account for the faster development of males. However, we cannot exclude the possibility that sex differences established at earlier stages may be triggered by glucose $24 \mathrm{~h}$ after insemination.

It could be argued that males develop faster than females because the reduced DNA content would allow faster completion of DNA replication. However, the findings of Burgoyne (1993) do not support this. The increased growth in male embryos may well be a consequence of differential gene expression caused either by the $Y$ chromosome or by the presence of a single $X$ chromosome. While Burgoyne (1993) presents evidence for a $Y$-chromosomal effect in mice, our results in cows imply a role for an increased activity of the X-linked gene products HPRT and G6PDH in female embryos. Apparently both these gene products play a role in controlling the amount of oxygen radicals. The formation of inosinate from hypoxanthine is catalysed by HPRT, but Downs and Dow (1991) demonstrated that glucose partially inhibits the activity of HPRT. This could increase degradation of hypoxanthine to ureate in reactions generating $\mathrm{H}_{2} \mathrm{O}_{2}$. Whereas the absence of HPRT inhibition may facilitate a decrease in peroxidation efficiently; even with single gene expression, a partial inhibition may require expression of both genes to do so. Therefore, it is possible that the difference in HPRT activity between the sexes can be expected to result in significantly different amounts of $\mathrm{H}_{2} \mathrm{O}_{2}$ only in the presence of glucose.

The activity of G6PDH controls the entry of glucose into the pentose phosphate pathway, which generates NADPH. With NADPH as electron source, glutathione-SH can reduce peroxides. The absence of exogenous glucose would most probably decrease the activity of the pentose phosphate pathway, which could be expected to diminish a sex-dependent difference in production of NADPH. High intracellular glucose utilization in the absence of exogenous glucose is unlikely. Khurana and Wales (1991) showed that glycogen degradation is inhibited in mouse embryos at a $20 \%$ oxygen concentration.

Consequently, increased gene expression of either HPRT or G6PDH may result in an abnormally low concentration of $\mathrm{H}_{2} \mathrm{O}_{2}$ in female embryos. The possibility that oxidative stress causes male embryos to develop faster than female embryos is supported by evidence of oxidation-induced gene expression (Sohal and Allen, 1990). For example, ADP-ribose transferase activity is stimulated by oxidative stress (Cerutti, 1985) and is required for mitogen-induced activation of human lymphocytes (Johnstone and Williams, 1982). Furthermore, $\mathrm{H}_{2} \mathrm{O}_{2}$ induces chromosomal puffing in Drosophila (Compton and McCarthy, 1978) and redox balance influences translation of mRNA (Douzou and Maurel, 1977).

The concept that differential gene expression causes the observed growth difference rests upon the assumption that gene activity occurs before the eight-cell stage. Although the major surge of transcription in cow embryos is generally accepted to occur at the eight- to 16-cell stage, the data of Barnes and First (1991) suggest that the first transcription events occur at the five-six-cell stage or earlier. Plante $e$ al. (1994), Marcucio et al. (1995) and Iwasaki et al. (1995) provided evidence of zygotic gene expression at the two-cell stage. It would make sense that housekeeping genes, such as those encoding HPRT and G6PDH, would be among the first to be activated.

Barnes and First (1991) and Plante et al. (1994) observed an increase in the growth rate of cow embryos exposed to the transcription inhibitor $\alpha$-amanitin. This may at first appear surprising. However, according to our hypothesis, blocking transcription would increase intracellular $\mathrm{H}_{2} \mathrm{O}_{2}$, and hence increase the growth rate. We intend to test our hypothesis further by examining the effect of blocking transcription on cow embryos cultured in glucose. The absence of the growth rate difference by the inhibition of transcription would be in agreement with our hypothesis.

The authors thank T. Hytti, T-M. Nieminen and J. Peippo for technical assistance and P-E. Bredbacka for useful suggestions with regard to the manuscript. FSH and LH were kindly provided by D. J. Bolt (USDA Animal Hormone Program, Beltsville, MD).

\section{References}

Avery B, Schmidt M and Greve T (1989) Sex determination of bovine embryos based on cleavage rates Acta Veterinaria Scandinavica 30 147-153

Avery B, Madison V and Greve T (1991) Sex and development in bovine in vitro-fertilized embryos Theriogenology 35 953-963

Avery B, Jorgensen CB, Madison V and Greve T (1992) Morphological development and sex of bovine in vitro-fertilized embryos Molecular Reproduction and Development 32 265-270

Barnes FL and Eyestone NL (1990) Early cleavage and the maternal zygotic transition in bovine embryos Theriogenology 33 141-152

Barnes FL and First NL (1991) Embryonic transcription in in vitro cultured bovine embryos Molecular Reproduction and Development 29 117-123

Bondioli KR, Ellis SB, Pryor JH, Williams MW and Harpold MM (1989) The use of male-specific chromosomal DNA fragments to determine the sex of bovine preimplantation embryos Theriogenology 31 95-104

Bredbacka P and Peippo J (1992) Sex diagnosis of ovine and bovine embryos by enzymatic amplification and digestion of DNA from the ZFX/ZFY locus Agricultural Science in Finland 1 233-238

Burgoyne PS (1993) A Y-chromosomal effect on blastocyst cell number in mice Development 117 341-345

Burgoyne PS and Thornhill AR (1995) Is Sry responsible for the more advanced development of male embryos compared to female embryos prior to gonadal sex differentiation? Genetical Research 65233 (Abstract)

Callesen H, Lovendahl P, Bak A and Greve T (1995) Factors affecting developmental stage of embryos recovered on day 7 from superovulated dairy cattle Journal of Animal Science 73 1539-1543

Cerutti PA (1985) Prooxidant states and fumor promotion Science 227 $375-381$

Downloaded from Bioscientifica.com at 04/26/2023 01:59:46PM 
Compton JL and McCarthy BJ (1978) Induction of the Drosophila heat shock response in isolated polytene nuclei Cell 14 191-201

Dominko T and First NL (1993) Male predominance of bovine embryos can be observed at the 2-cell stage Biology of Reproduction Supplement 148168 (Abstract)

Douzou P and Maurel P (1977) Ionic regulation in genetic translation systems Proceedings of the National Academy of Sciences USA 74 1013-1015

Downs SM and Dow MPD (1991) Hypoxanthine-maintained 2-cell block in mouse embryos: dependence of glucose and effect of hypoxanthine phosphoribosyltransferase inhibitors Biology of Reproduction 44 1025-1039

Epstein CJ, Smith S, Travis B and Tucker G (1978) Both X chromosomes function before visible $X$-chromosome inactivation in female mouse embryos Nature 274 500-502

de la Fuente R, Plante L and King WA (1993) X chromosome inactivation in the preattachment bovine embryo Theriogenology 39220 (Abstract)

Gutierrez A, Pintado B, Fuentes S, Payas A, Ugarte C and De La Fuente J (1993) Influence of micromanipulation and in vitro culture in the sex dependent loss of embryos 9th Meeting of the European Embryo Transfer Association 206 (Abstract)

Iwasaki S, Wilmut I and Campbell KHS (1995) Time-dependent RNA synthesis in early bovine embryos derived from in-vitro fertilization journal of Reproduction and Fertility Abstract Series 15 Abstract 174

Johnstone AP and Williams GT (1982) Role of DNA breaks and ADP-ribosyl transferase in eukaryotic differentiation demonstrated in human lymphocytes Nature $300368-370$

Khurana NK and Wales RG (1991) Effects of oxygen concentration on the metabolism of $\left[U-{ }^{14} U\right]$ glucose by mouse morulae and early blastocysts in vitro Reproduction, Fertility and Development 1 99-106

Kratzer PG and Gartler SM (1978) HGPRT activity changes in preimplantation mouse embryos Nature 274 503-504

Marcucio RS, Hopwood RM, Ignotz GG and Currie WB (1995) Translation of zygotically derived mRNA in a cell cycle specific manner in 2-cell cattle embryos Journal of Reproduction and Fertility Abstract Series 15 Abstract 46

Marquant-LeGuienne B, Nibart M, Guyader C, Kohen G, Esposito L, Thuard JM and Thibier M (1992) DNA probe sexing of young in vitro fertilized bovine embryos Theriogenology 37253 (Abstract)

Parrish JJ, Susko-Parrish J, Winer MA and First NL (1988) Capacitation of bovine sperm by heparin Biology of Reproduction 38 1171-1180
Peippo J and Bredbacka P (1995) Sex-related growth rate differences in mouse preimplantation embryos in vivo and in vitro Molecular Reproduction and Development 40 56-61

Plante L, Plante C, Shepherd DL and King WA (1994) Cleavage and ${ }^{3} \mathrm{H}$-uridine incorporation in bovine embryos of high in vitro developmental potential Molecular Reproduction and Development 39 375-383

Ray PF, Conaghan J, Winston RML and Handyside AH (1995) Increased number of cells and metabolic activity in male human preimplantation embryos following in vitro fertilization Journal of Reproduction and Fertility 104 165-171

Rieger D (1992) Relationships between energy metabolism and development of early mammalian embryos Theriogenology 37 75-93

Rosenkrans CF and First NL (1991) Culture of bovine zygotes to the blastocyst stage: effect of amino acids and vitamins Theriogenology 35266 (Abstract)

Saiki RK, Gelfand DH, Stoffel S, Scharf SJ, Higuchi R, Horn GT, Mullis KB and Erlich HA (1988) Primer-directed enzymatic amplification of DNA with a thermostable DNA polymerase Science 239 487-491

Sohal RS and Allen RG (1990) Oxidative stress as a causal factor in differentiation and aging: a unifying hypothesis Experimental Gerontology 25 499-522

Tsunoda Y, Tokunaga T and Sugie T (1985) Altered sex ratio of live young after transfer of fast- and slow-developing mouse embryos Gamete Research $\mathbf{1 2}$ 301-304

Valdivia RPA, Kunieda T, Azuma S and Toyoda Y (1993) PCR sexing and development rate differences in preimplantation mouse embryos fertilized and cultured in vitro Molecular Reproduction and Development 35 121-126

Xu KP, Yadav BR, King WA and Betteridge KJ (1992) Sex-related differences in developmental rates of bovine embryos produced and cultured in vitro Molecular Reproduction and Development 31 249-252

Yadav BR, King WA and Betteridge KJ (1993) Relationship between the completion of the first cleavage and the chromosomal complement, sex and developmental rates of bovine embryos generated in vitro Molecular Reproduction and Development 36 434-439

Zwingman T, Erickson RP, Boyer T and Ao A (1993) Transcription of the sex-determining region genes Sry and $Z f_{y}$ in the mouse preimplantation embryo Proceedings of the National Academy of Sciences USA 90 814-817 